\title{
Pengorganisasian Kelompok Sadar Wisata Melalui Program Desa Wisata di Desa Pujon Kidul
}

\author{
Nadiasari, Nurhadi \\ Jurusan Pendidikan Luar Sekolah \\ Fakultas Ilmu Pendidikan Universitas Negeri Malang \\ Email: nadsar0312@gmail.com
}

\begin{abstract}
The purpose of this study specifically is to describe the stages of organizing of Tourism Awareness Groups through the Tourism Village Program in Pujon Kidul Malang Regency. This study uses qualitative research methods using a type of case study approach. This research began with data collection using observation techniques, interviews and documentation studies. Then the data obtained is recorded and given a code. Then, in analyzing the data using data reduction, display data and drawing conclusions. After analyzing the data then checking the validity of the data, checking the validity of the data using triangulation technique. The results of this study that there are several stages of organizing Tourism Awareness Groups include: (1) socialization, (2) group formation, (3) program planning, (4) program implementation and (5) evaluation.
\end{abstract}

\section{Keywords: Organizing, Tourism Awareness Group, Tourism Village}

Abstrak: Tujuan penelitian ini adalah mendeskripsikan tahapan pengorganisasian Kelompok Sadar Wisata melalui Program Desa Wisata di Pujon Kidul Kabupaten Malang. Penelitian ini menggunakan pendekatan kualitatif dengan jenis penelitian studi kasus. Penelitian ini dimulai dengan pengumpulan data menggunakan teknik observasi, wawancara dan studi dokumentasi. Kemudian data yang diperoleh dicatat dan diberi kode. Kemudian, dianalisis dengan menggunakan teknik reduksi data, display, dan penarikan kesimpulan. Teknik pengecekan keabsahan data, yang digunakan adalah triangulasi. Hasil dari penelitian ini menunjukkan bahwa ada beberapa tahapan pengorganisasian Kelompok Sadar Wisata meliputi: (1) sosialisasi, (2) pembentukan kelompok, (3) perencanaan program, (4) pelaksanaan program dan (5) evaluasi.

\section{Kata Kunci: Pengorganisasian, Kelompok Sadar Wisata, Desa Wisata}

\section{PENDAHULUAN}

Pemberdayaan masyarakat merupakan upaya untuk memberikan daya atau penguatan kepada masyarakat untuk menentukan tindakan yang akan dilakukan sesuai dengan kebutuhan, sehingga mampu meningkatkan taraf hidup masyarakat. Menurut Sumodiningrat dalam Theresia (2014) "pemberdayaan masyarakat merupakan upaya untuk memandirikan masyarakat lewat perwujudan potensi kemampuan yang dimiliki”. Dalam proses pemberdayaan masyarakat diarahkan pada pengembangan sumber daya manusia dan penciptaan peluang sesuai dengan kebutuhan potensi masyarakat.

$$
\text { Pemberdayaan masyarakat }
$$
meliputi dua kelompok yang saling berkaitan, yakni masyarakat sebagai pihak yang diberdayakan dan pihak yang peduli sebagai pihak yang memberdayakan. Masyarakat sebagai pihak yang diberdayakan merupakan aktor utama dalam kegiatan pemberdayaan, dimana pihak yang memberdayakan hanya berfungsi sebagai pemberi stimulus, perangsang munculnya semangat, motivasi pada masyarakat untuk memberdayakan dirinya berdasarkan kebutuhan dan 
potensi yang dimiliki. Dalam praktik pemberdayaan masyarakat dibutuhkan suatu pengorganisasian, hal ini bertujuan untuk mempermudah proses pemberdayaan mencapai tujuan awal yang telah ditetapkan.

Pengorganisasian masyarakat merupakan suatu upaya pengelompokan masyarakat yang memiliki tujuan bersama, dimana untuk mewujudkan tujuan bersama diperlukan pembagian tugas dan tanggung jawab pada setiap individu. Pengorganisasian adalah pengelompokan berbagai kegiatan yang telah direncanakan untuk mencapai tujuan yang telah ditetapkan secara bersama. Menurut Winardi (2003:96) menyatakan bahwa "pengorganisasian (organizing) dapat dinyatakan sebagai proses dimana diupayakan agar struktur sesuatu organisasi tertentu, cocok dengan sasaran-sasarannya, sumbersumber dayanya, dan lingkungan". Adanya upaya menyelaraskan struktur organisasi dengan sasaran, sumber daya dan lingkungan merupakan proses dari suatu pengorganisasian

Pengorganisasian masyarakat merupakan proses dimana masyarakat mampu mengidentifikasi kebutuhan dan menentukan prioritas dari kebutuhannya, yang kemudian muncul usaha-usaha yang dilakukan untuk memenuhi kebutuhan yang telah diidentifikasi. Pemberdayaan masyarakat memiliki tujuan akhir memberikan daya untuk mengambil keputusan dan menentukan tindakan yang berkaitan dengan dirinya. Hal ini dilakukan melalui peningkatan kepercayaan diri untuk menggunakan daya yang dimiliki. Pengorganisasian kelompok merupakan komponen penting dalam mendukung keberhasilan suatu program. Secara umum pengertian pengorganisasian adalah sebagai proses penyusunan struktur organisasi sesuai dengan tujuan, sumber daya dan lingkungannya. Sebagaimana dikatakan Karyoto (2016:66) bahwa pengorganisasian (organizing) bisa diartikan (1) penentuan sumber dayadan kegiatan yang dibutuhkan untuk mencapai tujuan; (2) perancangan dan pengembangan suatu kelompok kerja yang dapat membawa ke arah pencapaian tujuan; (3) penugasan tanggung jawab tertentu; dan (4) pendelegasian wewenang kepada orang yang ditunjuk.

Kegiatan pengorganisasian merupakan suatu proses pendelegasian tugas kepada anggota kelompok. Sebelum adanya pendelegasian tugas kepada anggota kelompok terdapat proses penentuan sumber daya serta kegiatan untuk mencapai tujuan, selanjutnya adalah perancangan dan pengembangan dan yang terakhir adalah penugasan tanggung jawab. Aktivitas pariwisata dapat tumbuh diberbagai daerah, aktivitas pariwisata berfungsi menciptakan partisipasi, efisiensi, dan kesejahteraan. Pariwisata dianggap memberikan keuntungan bagi masyarakat, masyarakat yang sejahtera akan bersifat ingin memelihara manfaat dari aktivitas pariwisata. Menurut Mc. Intosh dan Goelder dalam Hadiwijoyo (2012:41) menyatakan bahwa "pariwisata adalah ilmu atau seni dan bisnis yang dapat menarik dan menghimpun pengunjung termasuk didalamnya berbagai akomodasi dan catering yang dibutuhkan dan diminati 
oleh pengunjung". Adanya pariwisata untuk menarik pengunjung dengan berbagai macam akomodasi yang diminati oleh pengunjung. Saat ini pariwisata telah merambah ke berbagai sektor, salah satu sektor pariwisata adalah konsep desa wisata.

Pengembangan desa wisata dapat memberikan dampak positif bagi masyarakat desa, seperti adanya lapangan pekerjaan untuk masyarakat yang dapat mengurangi jumlah pengangguran serta perpindahan masyarakat keluar desa untuk mencari lapangan pekerjaan. Menurut Darwis (2018:344) “....desa wisata yang mengusung konsep ekowisata akan membuat suatu desa dapat mempertahankan kelestarian alam dan budaya desanya". Dalam hal ini, adanya desa wisata yang berbasis ekowisata dengan menawarkan segala potensi yang dimiliki akan menjadikan masyarakat lebih menjaga kelestarian budaya dan alam untuk menarik minat wisatawan.

Salah satu program desa wisata yang ada adalah Desa Wisata Pujon Kidul. Berdasarkan studi pendahuluan yang telah dilakukan peneliti, gagasan Desa Wisata tersebut muncul dari Kepala Desa Pujon Kidul dengan melihat potensi alam, sosial budaya, pertanian dan peternakan yang ada di desa tersebut. Desa Wisata Pujon Kidul terealisasi dengan menggunakan dana desa dan percepatan pembangunan dilakukan di desa tersebut. Pada tahun 2015 terbentuklah Badan Usaha Milik Desa (BUMDES), Badan Usaha Milik Desa ini menjadi komponen penting dalam menggiatkan pemberdayaan masyarakat dari sisi sumber daya alam dan ekonomi masyarakat.

Dalam kegiatan pariwisata di desa tentu tidak lepas dari partisipasi masyarakat dalam pelaksanaannya. Masyarakat diorganisir agar mampu mewujudkan tujuan yang telah disepakati bersama dan dapat mengidentifikasi kebutuhan-kebutuhan serta menentukan prioritas, dan mengembangkan keyakinan untuk berusaha memenuhi kebutuhan sesuai dengan skala prioritas tadi berdasarkan atas sumber-sumber yang ada di masyarakat sendiri maupun yang berasal dari luar, dengan usaha secara gotong royong. Masyarakat Desa Pujon Kidul diorganisir melalui sebuah kelompok masyarakat yang disebut Kelompok Sadar Wisata. POKDARWIS adalah kelembagaan di tingkat masyarakat, yang memiliki kepedulian dan tanggung jawab serta berperan sebagai penggerak dalam mendukung terciptanya iklim kondusif bagi tumbuh berkembangnya kepariwisataan serta terwujudnya Sapta Pesona. Istilah Sapta Pesona yang dimaksudkan dalam penjelasan diatas adalah suatu konsep sadar wisata yang terkait dengan dukungan serta peran masyarakat untuk mewujudkan unsur aman, tertib, bersih, sejuk, indah, ramah dan unsur kenangan pada objek wisata yang ditawarkan kepada pengunjung. Adapun upaya sosial yang dilakukan oleh Pokdarwis adalah meningkatkan pemahaman kepariwisataan, meningkatkan peran dan partisipasi masyaakat dalam pembangunan kepariwisataan, meningkatkan nilai manfaat kepariwisataan bagi masyarakat/angggota Pokdarwis, dan 
mensukseskan

pembangunan

kepariwisataan.

Kelompok Sadar Wisata Desa Pujon dibentuk sejak tahun 2011 dan diresmikan pada tahun 2014 dengan nama Kelompok Sadar Wisata Capung Alas, peresmian tersebut bersamaan dengan peresmian Desa Pujon Kidul menjadi sebuah Desa Wisata. Kelompok Sadar Wisata Capung Alas beranggotakan para pemuda dan pemudi yang memiliki keinginan untuk membangun desanya, dalam pembentukan hingga pelaksanaan program tidak lepas dari peran kepala desa sebagai penasehat. Adanya peran serta dari masyarakat melalui pengorganisasian kelompok sadar wisata melalui program desa wisata akan memberikan dampak lebih mudahnya untuk mencapai tujuan bersama yang telah ditetapkan. Penelitian ini terfokus pada Pengorganisasian Kelompok Sadar Wisata Melalui Program Desa Wisata di Pujon Kidul Kabupaten Malang.

\section{METODE}

Penelitian ini dilakukan dengan menggunakan metode penelitian kualitatif. Peneliti menjadi pengumpul data utama dalam melakukan pengumpulan data dengan teknik pengumpulan data utama seperti yang dijelaskan pada paragraf sebelumnya. Peneliti tidak mengubah data yang diperoleh dari pandangan peristiwa dan segi pendirian responden.

Kehadiran peneliti di lapangan sangat diperlukan dalam mendukung terkumpulnya data, baik melalui wawancara, observasi, maupun studi dokumentasi. Pada proses penelitian, peneliti hadir setiap saat guna menggali data, baik secara lisan maupun tertulis. Sebagai individu yang sedang melakukan penelitian, maka maksud penelitian diungkapkan secara terbuka kepada subjek penelitian.

Penelitian ini dilaksanakan di Desa Wisata Pujon Kidul Kecamatan Pujon Kabupaten Malang. Alasan peneliti memilih lokasi peneltian pengorganisasian Kelompok Sadar Wisata adalah terdapat aktivitas terkait dengan pemberdayaan masyarakat dan layak untuk diteliti melalui pendidikan nonformal. Selain itu Kelompok Sadar Wisata Desa Pujon Kidul hingga saat ini berjalan aktif.

Sumber data pada teknik pengumpulan data ini di bagi menjadi dua sumber data diantaranya adalah sumber data primer, yakni data yang diperoleh secara langsung melalui wawancara yang dilakukan kepada Kepala Desa, Ketua Kelompok Sadar Wisata dan anggota Pokdarwis. Kemudian sumber data yang kedua adalah sumber data sekunder, yakni diperoleh dari dokumen atau arsip yang dimiliki oleh Kelompok Sadar Wisata Desa Pujon Kidul yang berisi sejarah, foto kegiatan, serta profil Desa Pujon Kidul, Kabupaten Malang.

Teknik pengumpulan data merupakan langkah awal dalam penelitian. Peneliti mengumpulkan data dalam penelitian ini menggunakan berbagai macam teknik agar tujuan dan fokus penelitian dapat dicapai. Pengumpulan data dilakukan dengan menggunakan teknik observasi, wawancara, dan studi dokumen. Analisis data merupakan tahapan penting dalam 
penelitian. Nasution (dalam Sugiyono, 2013:245) menyatakan "analisis telah dimulai sejak merumuskan dan menjelaskan masalah, sebelum terjun di lapangan, dan berlangsung terus sampai penulisan hasil penelitian". Jadi proses analisis telah dilakukan sejak merumuskan masalah hingga penulisan hasil penelitian. Sejalan dengan hal tersebut menurut Berg dalam Ulfatin (2013:203) menyatakan bahwa "teknik analisis sebagai proses analisis yang merubah hasil wawancara, catatan lapangan, dan macam-macam keterangan data, menjadi informasi yang sistematis".

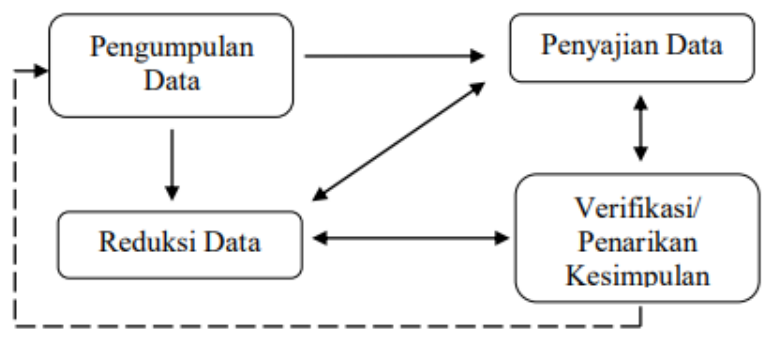

Gambar 1. Siklus Interaktif proses analisis data penelitian kualitatif (Milles \& Huberman dalam Ulfatin, 2013: 216).

Teknik pengecekan keabsahan data yang digunakan dalam penelitian ini adalah triangulasi yang menurut Moleong Patton dalam Moleong (2016:330) "triangulasi adalah pemeriksaan atau pengecekan keabsahan data dengan menggunakan (1) banyak sumber, (2) banyak metode atau teknik pengumpulan untuk konfirmasi data, (3) banyak waktu, dan (4) banyak penyidik atau investigator". Adapun teknik triangulasi yang digunakan adalah triangualsi sumber dan triangulasi metode atau teknik. Peneliti memilih triangulasi sumber yang menyatakan kebenaran informasi melalui informan yang berbeda-beda dan triangulasi metode atau teknik yang menyatakan mencari kebenaran informasi melalui metode pengumpulan data yang berbedabeda.

\section{HASIL}

Berdasarkan RPJMDes 2014, Desa Pujon Kidul merupakan salah satu Desa yang berada dalam wilayah Kabupaten Malang. Desa ini dalam segi geografis berada pada posisi $7^{\circ} 21^{\prime}-7^{\circ} 31^{\prime}$ lintang selatan dan $110^{\circ} 10^{\prime}-111^{\circ} 40^{\prime}$. Desa Pujon Kidul sebagaimana terletak di Kecamatan Pujon yang ermasuk daerah dengan dataran tinggi memiiliki karakteristik wilayah berupa perbukitan dan pegunungan. Lokasi lebih tepat berada di sekitar $1200 \mathrm{~m}$ diatas permukaan air laut. Lebih lanjut menurut data dari BPS Kabupaten Malang pada tahun 2014, selama tahun 2014 curah hujan yang terjadi di Desa Pujon Kidul rata-rata mencapai $2.000 \mathrm{~mm}$. Jumlah curah hujan terbanyak yaitu pada bulan Desember, yang mana pada bulan tersebut merupakan curah hujan tertinggi dalam kurun waktu 2010-2014 yang mencapai $1200 \mathrm{~mm}$.

Desa Wisata Pujon Kidul merupakan implementasi dari visi dan misi pembangunan desa pada tahun 2011. Berdasar pada visi dan misi pembangunan desa dan kesadaran diri dari kelompok pemuda dalam mengembangkan potensi desa maka muncul gagasan pengembangan desa wisata. Kelompok pemuda tersebut diresmikan menjadi Kelompok Sadar Wisata (Pokdarwis) pada tahun 2014. 
Kelompok pengelola ini diketuai oleh Bapak Samsul Hadi, yang memiliki kantor pengelola desa wisata di dusun Maron. Kelompok Sadar Wisata ini dikenal dengan sebutan Capung Alas. Terdapat berbagai macam wisata berbasis edukasi yang dikelola oleh kelompok sadar wisata yang membuat para wisatawan dapat menikmati pengalaman baru dalam berpariwisata. Edukasi pertanian yang menawarkan kegiatan berupa penyemaian, penanaman, perawatan hingga pemanenan sayur menjadikan wisatawan merasakan sensasi menjadi seorang petani. Edukasi peternakan yang menawarkan kegiatan berupa pemerahan susu, melihat proses pengumpulan susu di KUD setempat, serta berlanjut ke proses pengolahan susu. Produk olahan susu yang dibuat adalah stik susu, susu rasa, permen susu, dan yogurht. Kelompok Sadar Wisata juga menawarkan berbagai macam paket wisata, salah satunya adalah tinggal didesa. Wisatawan menginap di rumahrumah warga mengikuti kegiatan pemilik rumah serta tetap ada wisata edukasi.

Pelaksanaan program tidak lepas dari pengorganisasian masyarakat untuk mendukung program desa wisata. Adapun tahap-tahap dalam proses pengorganisasian masyarakat sebagai berikut: (1) sosialisasi, program desa wisata diawali dengan pertemuan bersama masyarakat pada tahun 2011, pertemuan tesebut di kemas dalam bentuk sosialisasi. Dalam kegiatan sosialisasi yang di pimpin oleh kepala desa materi yang di sampaikan adalah mengenai desa wisata dan potensi Sumber Daya Alam desa yang dapat di kembangkan, seperti pertanian dan peternakan yang dapat di kelola dengan model wisata edukasi; (2) pembentukan kelompok sadar wisata, yaitu pembentukan Kelompok Sadar Wisata Capung Alas Desa Pujon Kidul, para pemuda dan pejabat desa berkumpul lagi di balai desa untuk membentuk sebuah kelompok yang akan mengelola desa wisata yang di sebut dengan Lembaga Desa. Dalam pembentukan kelompok terdapat pembagian struktur organisasi yakni meliputi ketua kelompok, unit cafe sawah, tiketing dan parkir, divisi live in, seksi keamanaan dan ketertiban serta seksi kebersihan. Lembaga Desa Wisata berubah nama menjadi Kelompok Sadar Wisata pada tahun 2014 dengan di turunkannya surat keterangan dari desa serta diresmikannya Desa Pujon Kidul sebagai Desa Wisata; (3) perencanaan program desa wisata, yakni program desa wisata di fokuskan pada wisata berbasis edukasi. Di Desa Wisata Pujon Kidul terdapat edukasi pertanian, edukasi peternakan dan edukasi UMKM. Wisatawan yang datang di ajak untuk bercocok tanam, beternak dan praktek dalam pembuatan olahan susu. Selain perencanaan program wisata edukasi, kelompok sadar wisata juga merencanakan kegiatan untuk membersihkan lingkungan agar lebih bersih dan tertat; (4) tahap pelaksanaan program berawal dari upaya pembersihan desa yang dilaksanakan oleh kelompok sadar wisata, dimana Pokdarwis rutin melakukan pembersihan lingkungan serta penanaman tumbuhan untuk memperindah pemandangan. Selain itu upaya sosialiasai mengenai desa wisata juga tetap dilanjutkan guna 
menumbuhkan minat masayarakat terhadap desa wisata. Untuk program wisatanya terdapat wisata edukasi pertanian, peternakan dan UMKM. Pada tahun 2011 sudah ada wisatawan yang datang namun hanya kegiatan edukasi saja, di tahun 2012 ada rombongan wisatawan yang ingin menginap. Dengan adanya minat wisatawan untuk menginap maka di bentuklah home stay di rumah-rumah warga. Salah satunya adalah unit dari Desa Wisata Pujon Kidul yakni unit life in dimana wisatawan yang datang dapat menikmati liburan di Desa Pujon Kidul dalam waktu yang cukup lama. Untuk penginapannya ditempatkan di rumah warga yang dijadikan sebagai home stay, jadi wisatawan tinggal bersama di rumah warga. Untuk unit cafe sawah merupakan destinasi wisata yang menawarkan kuliner dengan keindahan alam, yakni persawahan dan pegunungan. Dalam pelaksanaan program juga terdapat pelatihan bagi anggota Pokdarwis untuk mengembangkan pengetahuan dan keterampilan anggota terkait dengan kepariwisataan, seperti pelatihan untuk pemandu wisata; dan (5) tahap evaluasi, yakni dalam kegiatan evaluasi melibatkan anggota Pokdarwis dan kepala desa. Dalam evaluasi kegiatan dibahas mengenai hasil dari pelaksanaan program dan hal yang telah dicapai dalam pelaksanaan program. Hasil dari program desa wisata mengenai minat masyarakat terhadap desa wisata semakin meningkat, dan terdapat tindak lanjut untuk penambahan wisata baru yang dapat dikunjungi perseorangan, hal ini bertujuan untuk menambah kunjungan wisatawan di Desa Wisata Pujon Kidul karena selama beberapa tahun terakhir tidak ada penambahan wisatawan yang signifikan. Wisata yang ditujukan untuk perseorangan tersebut di kemas dalam suatu cafe yang terletak di tengah persawahan warga, yang akhirnya dinamai Cafe Sawah.

\section{PEMBAHASAN}

Proses pengorganisasian masyarakat tidak selalu dilaksanakan secara runtut, proses pengorganisasian juga dapat berhasil atau gagal. Secara umum dan sederhana, keseluruhan proses diuraikan oleh Hann dan Topatimasang (2003:16) bahwa “(1) memulai pendekatan (2) memfasilitasi Proses (3) merancang strategi (4) mengarahkan tindakan (5) menata organisasi dan keberlangsungannya (6) membangun sistem pendukung". Pendekatan dimulai dengan masyarakat, kemudian menfasilitasi pertemuanpertemuan yang bertujuan untuk kelangsungan program, mengarahkan masyarakat untuk mencapai tujuan yang telah di tetapkan, menata organisasi guna keberhasilan suatu program karena suatu program akan berhasil apabila berhasil mengorganisasikan suatu kelompok yang ada di masyarakat, dan sebagai fasilitator juga bisa membangun sistem-sistem pendukung. Penataan organisasi dan keberlangsngannya Hann dan Topatimasang (2003:92) mengemukakan "membangun organisasi rakyat dalam pengertian ini adalah juga berarti membangun dan mengemangkan suatu struktur dan mekanisme yang menjadikan mereka, pada akhirnya, sebagai pelaku utama semua kegiatan 
organisai, mulai dari perencanaan, pelaksanaan sampai evaluasi dan tindak lanjutnya". Dapat diartikan bahwa proses pengorganisasian terdapat beberapa tahapan yakni tahap perencanaan yang kegiatannya dapat berupa sosialisasi, pembentukan kelompok dan perencanaan program. Tahap pelaksanaan program merupakan tahap perwujudan dari perencanaan program yang telah di rencanakan, pada akhirnya akan ada tahap evaluasi dan tindak lanjut yang berguna untuk melihat pencapaian suatu program dan rencana tindak lanjut yang akan di tempuh selanjutnya.

Tujuan pengorganisasian masyarakat adalah untuk memperbaiki kualitas hidup masyarakat melalui pendayagunaan sumber yang ada secara bersama-sama dalam suatu kelompok yang terorganisir. Menurut Rothman dalam Rustanto (2015:61) pengorganisasian kelompok memiliki tujuan untuk membangun pelayanan masyarakat dan program, mengarahkan dan mengkoordinasikan program, pengorganisasian masyarakat dan menjalin relasi, mengubah atau mereformasi kelembagaan di masyarakat dan pelaksanaannya, serta melakukan program relasi antarkomunitas dan pendidikan.

\section{Sosialisasi dalam Rangka Pemanfaatan Sumber Daya Alam Dan Pengenalan Desa Wisata}

Tahap awal pelaksanaan desa wisata adalah sosialiasai yang di laksanakan oleh pihak pemerintahan desa. Tujuan dilaksanakannya sosialisasi tersebut adalah untuk mengenalkan pada masyarakat mengenai program desa wisata. Dalam kegiatan sosialisai terdapat materi yang di sampaikan, yakni materi mengenai dan potensi Sumber Daya Alam desa yang dapat dikembangkan dan materi mengenai program desa wisata berbasis edukasi. Dalam materi yang pertama adalah mengenai potensi yang ada di desa, meliputi potensi pertanian dan peternakan, serta bagaimana cara mengembangkan sumber daya alam tersebut melalui materi kedua yakni program desa wisata. Melalui program desa wisata akan berdampak pada perkembangan sektor pertanian dan peterakan yang nantinya akan berdampak pada keberdayaan warga. Maka dapat dikatakan dengan adanya sosialiasasi dalam pengenalan desa wisata ini untuk memanfaatkan potensi yang ada bersama masyarakat sekitar.

Menurut Theresia (2014:220) "sosialisasi merupakan upaya megkomunikasikan kegiatan untuk menciptakan dialog dengan masyarakat. melalui sosialosasi akan membantu untuk meningkatkan pemahaman masyarakat dan pihak terkait tentang program dan atau kegiatan pembangunan berbasis masyarakat yang telah direncanakan".

Berdasarkan hasil penelitian yang telah dipaparkan diatas maka dapat diketahui bahwa sosialisasi difasilitasi oleh pihak pemerintahan desa yang di pimpin oleh kepala desa setempat. Sosialiasasi dihadiri oleh pemerintah desa dan masyarakat sekitar, adanya sosialisasi bertujuan untuk menyampaikan kepada masyarakat sekitar mengenai potensi yang ada didesa dan cara pengembangannya 
melalui program desa wisata. Respon masyarakat terhadap sosialisasi desa wisata bermacam-macam, ada yang setuju terhadap program tersebut dan ada yang tidak setuju dengan program tersebut.

\section{Pembentukan Kelompok Sadar Wisata}

Berdasarkan hasil temuan
penelitian terdapat kegiatan pembentukan kelompok yang dihadiri para pemuda dan pemerintah desa. Hasil dari pertemuan ini adalah terbentuknya suatu kelompok masyarakat pengelola wisata yakni Kelompok Sadar Wisata. Kelompok ini beranggotakan pemuda dan beberapa anggota dari pemerintahan desa. Setelah pembentukan kelompok maka terdapat pembagian tugas tiap individu dalam suatu organisasi. Langkah awal pembentukan struktur organisasi adalah pemilihan ketua dan dilanjutkan dengan kepengurusan lainnya. Tugas yang dilaksanakan nantinya sesuai dengan keputusan bersama dalam forum. Contohnya ketua yang bertanggung jawab serta mengkoordinir anggota kelompoknya.

Pembentukan Kelompok Sadar

Wisata dilaksanakan setelah tahap sosialisasi, pembentukan kelompok dilakukan guna mendukung program desa wisata sebagai pengelola program desa wisata. Dalam pembentukan kelompok pengelola desa wisata, kegiatan pembentukan kelompok di laksanakan setelah tahap sosialisasi dengan masyarakat. Pembentukan kelompok dilaksanakan pada tanggal 23 Juli 2011, yang dihadiri oleh kelompok pemuda dan pemerintah desa. Kelompok

pemuda yang hadir dalam kegiatan tersebut merupakan kelompok pemuda yang telah paham mengenai desa wisata sehingga terbentuklah Kelompok Sadar Wisata.

Pembentukan kelompok adalah strategi awal dalam pengorganisasian suatu kelompok, dalam kelompok ini proses sosialisasi akan berlangsung. Dengan demikian tujuan dari suatu organisasi akan tercapai, selain itu di dalam kelompok seorang individu dapat memenuhi kebutuhan hidup dan mengembangkan potensi serta aktualisasi diri. Yusuf (dalam Huraerah, 2010:3) mengemukakan bahwa kelompok adalah sejumlah individu yang berinteraksi dengan sesamanya secara bertatap muka atau serangkaian pertemuan, dimana masing-masing anggota tersebut saling menerima impresi atau persepsi anggota lain dalam suatu waktu tertentu dan menimbulkan pertanyaan-pertanyaan kemudian, yang membuat masing-masing anggota bereaksi sebagai reaksi individual.

Setiap individu dapat berinteraksi di dalam kelompok secara langsung, terdapat beberapa pengertian kelompok berdasarkan sudut pandangnya. Seperti kelompok berdasarkan tujuannya, yakni menurut Iskandar dalam Huraerah (2010:4) "kelompok adalah suatu unit yang terdiri dari dua orang atau lebih, dan berada pada satu kelompok untuk satu tujuan dan mereka mempertimbangkan bahwa kontaknya mempunyai arti”.

Menurut Winardi (2011:27)
menyatakan "apabila orang-orang
berkumpul menjadi satu, dan kemudian
mereka secara formal mencapai


persetujuan untuk mengkombinasi upaya mereka untuk mencapai tujuan bersama, maka hasilnya berupa sebuah organisasi"'.

Pengorganisasian menurut $\mathrm{C}$. Certo dalam Winardi (2003:22) bahwa proses dimana ditetapkan penggunaan secara teratur, semua sumber-sumber daya di dalam sistem manajemen yang ada. Pengorganisasian mencakup tindakan yang dilakukan oleh individu dalam suatu kelompok. Adapun kegiatan yang dilakukan merupakan usaha untuk mencapai tujuan dari kelompok. Pengorganisasian dapat dilakukan dengan membagi tugas yang harus dikerjakan, siapa yang mengerjakan, bagaimana tugasnya, siapa yang bertanggung jawab pada tugas tersebut. Pembagian tugasnya juga sesuai dengan keahlian masing-masing anggota yang ada dalam kelompok, yang ahli dalam pemasaran maka diberi tugas sebagai marketing dan lain sebagainya.

Dalam proses pengorganisasian terdapat pembagian tugas dalam melaksanakan tugas sesuai dengan tujuam program yang telah di tetapkan bersama. Pembagian tugas dalam Kelompok Sadar Wisata Pujon Kidul dilakukan secara otodidak, dimana anggota kelompok bebas memilih bidang yang sesuai dengan keahlinannya. Tidak ada paksaan untuk anggota kelompok berada pada bidang yang bukan keahliannya. Namun sebelum dilakukan pembagian tugas telah disetujui orang yang menjadi ketua dalam kelompok.

\section{Perencanaan Program Desa Wisata oleh Kelompok Sadar Wisata}

Setelah adanya pembentukan dan pembagian tugas dalam kelompok terlaksana maka anggota Pokdarwis menyusun rencana program yang akan dilaksanakan. Perencanaan program dilakukan untuk mencapai suatu tujua dari organisasi yang mana telah di setujui secara bersama. Perencanaan suatu program menjadi tolak ukur dalam keberhasilan dalam suatu program yagg dilaksanakan. Perencanaan merupakan penentuan tujuan yang akan dicapai atau yang akan dilakukan, bagaimana, dan oleh siapa. Menurut Theresia (2014:221) "menyusun rencana kegiatan kelompok, berdasarkan hasil kajian meliputi: Memprioritaskan dan menganalisa masalah-masalah, identifikasi alternatif pemecahan masalah yang terbaik, identifikasi sumbersaya yang tersedia untuk pemecahan masalah, pembangunan berbasis rencana kegiatan serta pengorganisasian pelaksanaannya". Selaras dengan hal tersebut Sjamsulbachri (2004:15) menjelaskan bahwa "perencanaan merupakan proses menentukan tujuan yang ingin dicapai dan strategi apa yang akan digunakan dalam usaha pencapaian tersebut".

Berdasarkan hasil penelitian yang telah dijabarkan, setelah pembentukan dan pembagian tugas dalam kelompok maka dilakukan perencanaan program. Perencanan program membahas mengenai apa saja yang akan dilaksanakan sebagai pengelola program desa wisata. Perencanaan program direncanakan meliputi wisata apa yang akan di jalankan dalam program desa wisata, dalam perencanaan progam di peroleh hasil bahwa di Desa Wisata Pujon Kidul akan ada wisata edukasi. 
Wisata edukasi tersebut meliputi edukasi pertanian, edukasi peternakan dan edukasi UMKM. Edukasi pertanian dalam perencanaan nya wisatawan yang berkunjung akan di ajak langsung menuju lahan pertanian milik warga dan melakukan cocok tanam. Lalu untuk edukasi peternakan wisatawan yang hadir di ajak langsung mengunjungi peternakan milik warga serta melihat proses perawatan sapi perah serta bisa ikut dalam proses pemerahan susu sapi. Sedangkan untuk edukasi UMKM wisatawan yang berkunjung diajak untuk melihat dan mempraktekkan pengolahan susu sapi menjadi produk olahan seperti susu rasa, permen susu, dodol susu, krupuk susu dan lain sebagainya. Melalui perencanaan program yang dilaksanakan oleh Pokdarwis dapat dijadikan tolak ukur dalam keberhasilan suatu program yang dilaksanakan. Selain perencanaan wisata berbasis edukasi, Kelompok Sadar Wisata juga merencanakan kegiatan pembersihan desa dan penataan ulang desa dengan kegiatan pembersihan desa dan penanaman tumbuhan di sekitar desa. Lalu kelompok juga merencanakan untuk terus melakukan kegiatan sosialisasi terkait desa wisata guna menumbuhkan minat masyarakat terhadap desa wisata.

\section{Pelaksanaan Program Desa Wisata oleh Kelompok Sadar Wisata}

Pelaksanaan program merupakan penugasan anggota kelompok dengan melihat kondisi lingkungan serta sesuai dengan kewenangan yang telah dilimpahkan terhadap setiap individu untuk mencapai tujuan bersama. Dalam pelaksanaan program komunikasi menjadi unsur penting untuk mencapai tujuan bersama dalam suatu kelompok, hal ini menyangkut proses penyampaian informasi dan kejelasan suatu informasi terhadap anggota kelompok yang lain. Dalam pelaksanaan suatu program dapat berhasil, kurang berhasil, ataupun gagal apabila dilihat dari hasil yang di capai. Karena dalam pelaksanaan program terdapat berbagai unsur yang mendukung ataupun menghambat suatu proses pelaksanaan program. Menurut Theresia (2014:221) "rencana yang telah disusun bersama dengan dukungan fasilitasi dari pendamping selanjutnya diimplementasikan dalam kegiatan yang konkrit dengan tetap memperhatikan realisasi dan rencana awal".

Berdasarkan hasil penelitian yang telah dipaparkan proses pelaksanaan program di awali dengan wisata berbasis edukasi, yaitu edukasi pertanian, peternakan dan UMKM. Pada tahun 2011 sudah ada wisatawan yang datang namun hanya kegiatan edukasi saja, di tahun 2012 ada rombongan wisatawan yang ingin menginap. Dengan adanya minat wisatawan untuk menginap maka di bentuklah homestay di rumah-rumah warga. Dalam pelaksanaan program juga terdapat pelatihan bagi anggota Pokdarwis untuk mengembangkan pengetahuan dan keterampilan anggota terkait dengan kepariwisataan, seperti pelatihan untuk pemandu wisata.

\section{Evaluasi Program Desa Wisata oleh Kelompok Sadar Wisata}

Tahap akhir dari suatu pengorganisasian adalah evaluasi kegiatan, evaluasi merupakan kegiatan 
untuk melihat keberhasilan suatu program yang dilaksanakan. Tahap evaluasi penting dilakukan untuk melihat sejauh mana keberhasilan suatu program serta membuat rencana baru untuk tindak lanjut hasil dari evaluasi tersebut. Menurut Theresia (2014:222) "memantau proses dan hasil kegiatan secara terus menerus secara partisipatif (participatory monitoring and evaluation/ PME) PME ini dilakukan secara mendalam pada semua tahapan pembengunan berbasis masyarakat agar prosesnya berjalan dengan tujuannya". Dapat dikatakan bahwa evaluasi merupakan suatu proses penilaian baik dari segi prosesnya amaupun hasil serta dampak yang di peroleh dari suatu program guna menyusun proses perbaikan apabila diperlukan. Selaras dengan hal itu Menurut Arikunto (1993:297) “melakukan evaluasi program adalah kegiatan yang dimaksudkan untuk mengetahui seberapa tinggi tingkat keberhasilan dari kegiatan yang direncanakan". Jadi evaluasi program berfungsi untuk mengetahui tingkat keberhasilan suatu program yang dijalankan, termasuk berhasil atau tidaknya suatu program yang dilaksanakan.

Berdasarkan pada hasil temuan peneliti, setelah tahap pelaksanaan program terdapat tahap evaluasi program untuk melihat sejauh mana keberhasilan program tersebut dalam pelaksanaannya. Tahap evaluasi dilakukan guna menindaklanjuti temuan-temuan yang nantinya dapat memberikan perbaikan terhadap suatu program. Kegiatan evaluasi program yang dilaksanakan oleh Pokdarwis beserta pemerintah desa.
Dalam kegiatan evaluasi membahas mengenai pencapaian program yang telah dilaksanakan, untuk wisata edukasi tidak begitu terdapat peningkatan jumlah pengunjung yang signifikan. Sehingga untuk menanggulangi hal tersebut maka direncanakan pembuatan wisata yang dapat di kunjungi oleh perseorangan, yakni cafe sawah. Selain itu evaluasi diadakan mengenai respon masyarakat dengan adanya Desa Wisata Pujon Kidul, hasil evaluasinya adalah minat masyarakat terhadap desa wisata terus meningkat. Dilihat dari masyarakat yang antusias terhadap desa wisata dan sudah paham mengenai arah dari desa wisata.

\section{SIMPULAN}

Kesimpulan berdasarkan temuan penelitian yang diperoleh dari lapangan dan hasil pembahasan yang dilakukan peneliti dapat disimpulkan bahwa Pengorganisasian Masyarakat melalui Program Desa Wisata di Desa Pujon Kidul dilakukan melalui tahapan sebagai berikut:

Sosialisasi dalam rangka pemanfaatan sumber daya dan pengenalan desa wisata, meliputi potensi pertanian dan peternakan, serta bagaimana cara mengembangkan sumber daya alam tersebut melalui materi kedua yakni program desa wisata.

Pembentukan kelompok sadar wisata guna mendukung program desa wisata yang dilanjutkan membentuk struktur kelompok dan pembagian tugas tiap individu dalam kelompok.

Perencanaan program desa wisata oleh kelompok sadar wisata yang terfokus pada kegiatan wisata berbasis edukasi pertanian mulai dari pembibitan, 
penyemainan hingga panen, edukasi peternakan mulai dari perawatan sampai pemerahan, dan edukasi UMKM meliputi proses pengolahan susu menjadi produk-produk olahan.

Pelaksanaan program meliputi program penataan destinasi wisata, pengaturan tempat penginapan, dan pelatihan bagi anggota Pokdarwis untuk mengembangkan pengetahuan dan keterampilan anggota terkait dengan kepariwisataan, seperti pelatihan untuk pemandu wisata guna meningkatkan pengetahuan dan kemampuan pengelola program desa wisata.

Evaluasi yang dilakukan guna mengukur capaian program yang telah dilaksanakan dan menindaklanjuti temuan-temuan yang nantinya dapat memberikan perbaikan program desa wisata. 


\section{DAFTAR RUJUKAN}

Arikunto, Suharsimi. 1993. Manajemen Pengajaran Secara Manusiawi. Jakarta: Rineka Cipta.

Darwis, S Rudi, dkk. 2018. Pengembangan Desa wisata Melalui Konsep Community Based Tourism. PROSIDING KS: RISET \& PKM, 2 (3), 301-444. Dari: http://jurnal.unpad.ac.id/prosiding/art icle/view/13581/6411.

Hadiwijoyo, S Suryo. 2012. Perencanaan Pariwisata Perdesaan Berbasis Masyarakat. Yogyakarta: Graha Ilmu.

Huraerah, Abu \& Purwanto. 2010. Dinamika Kelompok - Konsep dan Aplikasi. Bandung: PT Refika Aditama.

Karyoto. 2016. Dasar-Dasar ManajemenTeori, Definisi dan Kosep. Yogyakarta: CV Andi Offset.

Moleong, Lexy J. 2014. Metodologi Penelitian Kualitatif. Bandung: PT Remaja Rosdakarya.

Rustanto, Bambang. 2015. Menangani Kemiskinan. Bandung: PT Remaja Rosdakarya.

Sjamsulbachri, Asep. 2004. Akuntansi Manajemen, Edisi Pertama. Bandung : Kencana Utama.
Sugiyono. 2013. Metode Penelitian Pendidikan Pendekatan Kuantitatif, Kualitatif, dan $R \& D$. Bandung: Alfbeta.

Sugiyono. 2017. Metode Penelitian Pendidikan Pendekatan Kuantitatif, Kualitatif, dan $R \& D$. Bandung: Alfbeta.

Topatimasang, Tan, Jo Hann \& Roem 2003. Mengorganisir Rakyat Refleksi Pengalaman Pengorganisasian Rakyat di Asia Tenggara. Yogyakarta: SEAPCP-ReaD.

Theresia, Aprilia, dkk. 2014. Pembangunan Berbasis Masyarakat Acuan Bagi Praktisi, Akademisi, dan Pemerhati Pengembangan Masyarakat. Bandung: CV. Alfabeta

Ulfatin, Nurul. 2013. Metode Penelitian Kualitatif di Bidang Pendidikan. Malang : Fakultas Ilmu Pendidikan Universitas Negeri Malang.

Winardi, J. 2003. Teori Organisasi dan Pengorganisasian vol.2. Jakarta : Raja Grafindo Persada. 